\title{
Marble-like chûnnam in the 18th- and 19th-century Madras Presidency
}

\author{
Anantanarayanan Raman* \\ Charles Sturt University, PO Box 883, Orange, NSW 2800, Australia.
}

(Received 25 September 2019; revised 07 November 2019)

\begin{abstract}
Lime (calcined limestone), referred as çûnam and çûnnạm ('chûnnam') was used in the Indian subcontinent for ages. In the Tamizh country, lime was referred as çûnnāmpu. The nature and quality chûnnam used in the Madras presidency are formally recorded in various published reports by the British either living in or visiting Madras from the 18th century. All of them consistently remark that the quality of chûnnam used in building human residences and other buildings was of superior quality than that used for the same purpose elsewhere in India. The limestone for making chûnnam was extracted from (i) inland quarries and (ii) beached seashells. The latter was deemed of superior quality. In the Tamizh country in particular, a few other biological materials were added to lime mortar to achieve quicker and better hardening. In the Madras presidency, builders and bricklayers, used to add jaggery solution, egg albumin, clarified butter, and freshly curdled yoghurt, and talc schist (balapong) to the lime mortar. Many of the contemporary construction engineers and architects are presently loudly talking on the validity and usefulness of using lime mortar, embellished with plant fibres and plant extracts, supplemented by traditional practice of grinding.
\end{abstract}

Key words: Çûnnāmbu, Jaggery, John Smith, Kaḍkkāi, Limestone Mortar, Magnesite, Portland Cement, Seashells, Vegetable Material.

\section{Introduction}

The chief engineer of the Public Works Department of Government of Tamil Nadu, referring to the restoration of an iconic building in Madras city - the Hūmayūn Mahal (Figure 1) remarked in the Hindu dated 21 September $2019^{1}$ as:

We are planning to use bulls to churn lime

\footnotetext{
DOI: 10.16943/ijhs/2020/v55i1/152340

*Email: araman@csu.edu.au, anant@raman.id.au

${ }^{1}$ (https://www.thehindu.com/news/cities/chennai/engineers-hitrewind-for-heritage-revamp-Humayun-mahal-resto-ration-to-seerevival-of-traditional-construction-techniques/article29472801.ece, accessed 21 September 2019).
}

mortar instead of a mixer, for better compressive strength and long-lasting life. We found that structures built with lime mortar achieved more strength as they grew older, compared to concrete buildings that gained strength only up to $50-60$ years.

Mohammed Ali Khan Wallajah (1717-1795), the Nawab ruling this part of southern India, desired to build a permanent, palatial residence in Chepauk (coastal segment of Triplicane) and built the Chepauk Palace in 1768. This palace complex consisted of two mahal-s: the Kālsā Mahal and the Hûmayûn Mahal (Figure 1). This palace complex spread over 117 acres, stretching from the Cooum 


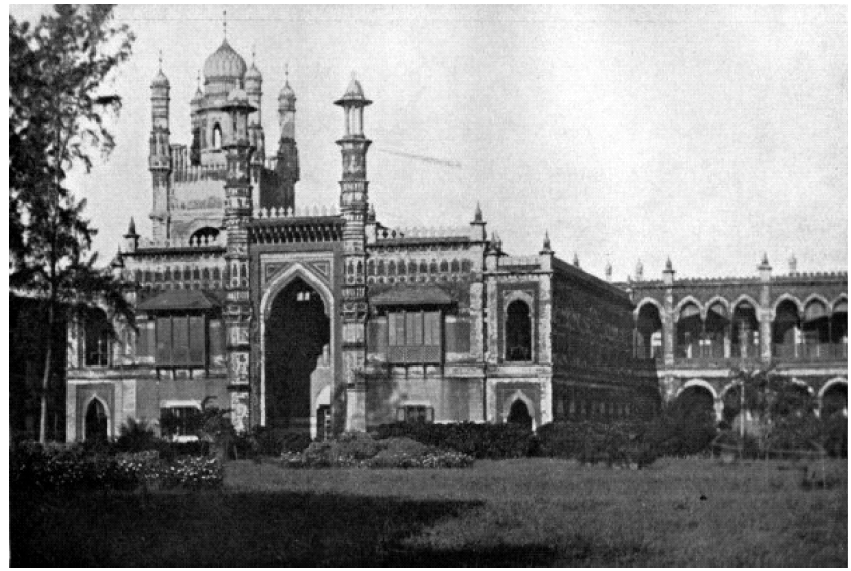

Figure 1 The Chepauk Palace complex. The Hûmayûn Mahal with its tower with four minarets is visible in the background, c. 1905 (Source: Courtesy of Special Collections, University of Houston Libraries). ${ }^{2}$

River in the north to the Pycrofts Road (presently Bharati Salai) in the south. Parts of Hûmayûn Mahal were restored by Robert Fellowes Chisholm (1840-1915, Consulting Architect to the Government of Madras) in the mid19th century (Srinivasachari 1939).

Lime $\left(\mathrm{CaO}, \mathrm{Ca}[\mathrm{OH}]_{2}\right.$, calcined limestone, calciteincluding sedimentary rock), referred as çûnam and çûnnam (hereafter spelt 'chûnnam') was used in the Indian subcontinent for ages. In the Tamizh country, lime was referred as çûnṇammpu. According to the Merriam-Webster Dictionary chûnnam is a 'cement' or 'plaster' used in India, usually highly polished and decorated with paintings ${ }^{3}$. Thomas Lehmann (Abteilung Neusprachliche Südasienstudien-Tamil, Süd-AsienInstitut, Universität Heidelberg) explained the etymology of çûnṇāmpu as follows (email, 13 August 2019):

The word çûnnāmpu is first attested in the 12th century war poem Kalingathu-p-parani. ${ }^{4}$ According to the Tamil Lexicon of the Uni-

\footnotetext{
${ }^{2}$ https://en.wikipedia.org/wiki/Chepauk_Palace\# /media/File:\Chepauk_Palace.jpg,public domain.

${ }^{3}$ https://www.merriam-webster.com/dictionary/chunam, accessed 11 August 2019.

${ }^{4}$ Kalingathu-p-parani is a war poem composed by Jayamkondār in celebration of the grand victory of Kulôtunga Çôlā I (1070-1120 CE, of the later Çola dynasty) and his commander Karunakara-tfôndaiman over Anantavarman Chôdaganga Devā, king of Kalinga Désā (most of modern Orissa and some of northern coastal Andhra
}

versity of Madras çûnnāmpu is derived from çûnṇa (Prākrit). It is possible that the word çûnñămpu was in use before the 12th century. Lime was used in the Tamizh country in the first millennium, but maybe with another name. $^{5}$

The Mandagapattu cave temple inscription of Mahéndra Varmā I (c. 7th century CE) articulates that the rockcut shrine made in Madagapattu $\left(12^{\circ} 6^{\prime} \mathrm{N}, 79^{\circ} 27^{\prime} \mathrm{E}\right.$, Villupuram District) by King Vicitracita for the Hindu Divine Trinity was constructed without bricks, timber, metal, and mortar. This articulation confirms that the people in Tamizh country of the 7th century knew and built temples and shrines using brick, timber, metal, and mortar (Ramaswami 1971, Balaji 2017).

Large city-like congregations of Harappa (c. 2600 BCE) included sophisticated sanitation networks (Lal 1997). The mortars used in constructing those networks were of mud paste. They also seem to have known and made use of vajralépa. Varāhamihira (6th century CE) explains vajralépa ${ }^{6}$ in Brhtsamhitā as an adamantine glue made as a composite paste, prepared by grinding various biological and mineral substances. It included resinous secretions of plants, e.g., Commiphora wightii $([=C$. mukul $]$, Bursearceae) and of animals, e.g., Kerria lacca (Insecta: Kerridae) in addition to metals, such as mercury (Sastri and Bhat 1946). Vajralépa was used primarily in temples $^{7}$ and palaces, implying that it was affordable to the wealthy. To fix the idol onto the pedestal, vajralépa was applied at the installation points (brahmasthāna-s) in

Pradesh and inland Telengana, and parts of Chhattisgarh) in the 12th century.

${ }^{5}$ The term sutai was used to imply lime $\left(\mathrm{CaCO}_{3}\right)$ and lime mortar in the Tamizh country before the 12th century. Çankamperiod poetry, e.g., Aka-nānūru, Pura-nānūru, Nédunalvādai (1st century BCE-2nd century $\mathrm{CE}$ ) use the word sutai indicating that the Tamizh people knew of $\mathrm{CaCO}_{3}$ and $\mathrm{CaCO}_{3}$ mortar. Because of the enormous heat, the lime kilns, it seems, were used as torture rooms. In Çékkizhār's Périya Purānam (also 12th century CE) verses 1360-1368 (https://shaivam.org.devotees/the-puranam-ofthirunavukkarasar, accessed 15 August 2019) refer to the admonishment of Firunāvuk-karasar (6th-7th centuries), a Śaiva Saint, for seven days to a lime kiln by Mahéndra Varma I of the Pallava dynasty (r. 600-630 CE) ruling from Kānçipuram. Only literary evidence exists for this claim (personal communication, Venkat Prakash, Indologie, Institut Français de Pondichéry, email, 14 August 2019).

${ }^{6}$ Vajralépa (Sanskrit): vajra — diamond, lépa - paste, glue

${ }^{7}$ Use of vajralépa in ancient Hindu temples is explained in Raddock (2011, p. 114, footnote 680 ). 
temples (Chakrabarti 1998, Indorf 2004). Its high tensile and compression strength is currently established as 100 $\mathrm{kPa}$ (Atalkar et al. 2006).

Mahmud Shah (r. 1538-1554), the ruler of Ahmedabad (modern Gujarat), on being repeatedly harassed by the Portuguese in Surat, instructed his army commander Safi Agā to build an extra-strong fort there in the 16th century. Safi Agā built the Surat fort in 1540-1546, surrounded by two - each 20 yards $(18.3 \mathrm{~m})$ wide - waterfilled moats. Walls of the fort and the moats were built using stone, chûnnam mortar, and burnt brick (Elliott 1873, p. 575). Stone grinders pulled by either single or a pair of bulls to grind lime mortar were usually used. Stunning details of the different mortars used in building the Bibika-Maqbara in Aurangabad by Aurangazeb in memory of his principal wife Dilras Banu in 1660 are available (Singh et al. 2014).

\subsection{Lime mortar elsewhere and the Portland cement}

Romans of the later Roman Republic (c. 500-0 BCE) used a composite, referred as the Roman concrete (RoC, opus caementicum) to construct submerged pillars in harbours and walls of aqueducts (Lamprecht 2008). This was a hydraulic-setting material, which hardened within minutes after application under water. Volcanic ash in RoC prevented cracks in built structures. By the mid-1st century RoC was used extensively in Rome and other nearby nations, with a few minor changes made to its composition in later years (Courland 2011, p. 396). The pyramids of ancient Egypt are yet another remarkable landmark in the use of mortars: the Egyptians used limestone-gypsum mortars (Davidovits 2006, p. 284; Jana 2007).

John Smeaton (1724-1792), a British engineer and builder, first established the scientific relevance of hydraulic lime by improving the previously known lime mortar, by adding aggregates of pebbles and brick powder that hardened more quickly on combining with water than the mortars used previously. Smeaton fired the limestone-including clay, until it turned into a stony residue, which was then fine ground. He used the pulverized material in rebuilding the Eddystone lighthouse (Cornwall, England) in $1756 .^{8}$ This was remarkable be-

\footnotetext{
${ }^{8}$ First built by Henry Winstanley (1644-1709) in 1696-1699. John
} Rudyard re-built it in 1708-1709. Smeaton's effort was the third. cause the hydraulic lime he used, set rapidly securing the stone blocks laid under water (Adams 189, p. 380). Smeaton's work paved the foundation for developing concrete in later years. In 1894, Joseph Aspdin (1778-1855), a British bricklayer, invented the modern cement (Rinde 2015) and named it 'Portland cement' after burning thinground chalk and clay in a kiln until all the included $\mathrm{CO}_{2}$ was completely removed. Aspdin was the first to heat $\mathrm{Al}-$ and Si-including materials to the point of vitrification, enabling fusion among the different minerals in the composite. He improved the procedure by rectifying the proportions of limestone and clay before powdering and burning to residue, and finally grinding that into finished cement (Crider 1907). ${ }^{9}$

The Portland cement (PC) and concrete are incredible materials that changed the complexion of the present human society. Besides acknowledging the fact that growth and performance of construction industry are major and critical indices of economic growth and development (Ofori 2015), construction of humongous buildings represent superb science and fascinating technology (e.g., Burj Khalifa, Dubai). Such super-tall buildings exemplify the brilliance of human intellect, since many natural forces need to be factored and countered while carrying out such challenging tasks. The $c .500 \mathrm{~m}$ tall Taipei 101 (built in 2004), stands majestically in Taipei, withstanding the periodical earthquakes and tropical storms in Taiwan. One scientific marvel in Taipei 101 is the inclusion of a c. 650 tonne steel ball suspended in the centre from the 92 nd to the 87 th floor - the tuned-mass damper — to mitigate vibration and maintain stability especially during strong winds (Tuan and Shang 2014).

Industrial-scale production of PC started first in India in the South-India Industrials Limited in Washermanpet (Vannār-péttai, $13^{\circ} 6^{\prime} \mathrm{N}, 80^{\circ} 17^{\prime} \mathrm{E}$ ) in 1904 , which produced 10,000 metric tonnes of PC annually. Seashells were the principal raw material. Three other PC factories concurrently commenced in Porbandar (Gujarat), Katni (Madhya Pradesh), and Bundi (Rajasthan) a decade later

\footnotetext{
${ }^{9}$ Aspdin named this material after Portland, since it closely resembled the high-quality limestone of Portland, England. A copy of his patent application entitled Aspdin's improvements in the mode of producing an artificial stone and approval by the British Chancery (https://en.wikipedia.org/wiki/Joseph_ Aspdin\#/media/File: Joseph_Aspdin-BP_5022_2.jpg) is freely accessible.
} 
(Bagchi 1939, p. 482). Massey \& Company Limited ${ }^{10}$ on the Cochrane Canal Road, North Madras, marketed $<$ Johnson's Elephant Brand Cement> in 1910 (Playne et al. 1914-1915, p. 161). What is not clear is whether the Elephant Brand cement was the one produced by SouthIndia Industrials or was imported from elsewhere and marketed by Massey \& Co. Unfortunately, no further details of the South-India Industrials Limited are trackable.

\section{Madras Chûnnam in the 18th Century}

\subsection{On its apparent quality}

The nature and quality of chûnnam used in the Madras presidency are formally recorded in various published reports by the British either living in or visiting Madras from the 18th century. All of them consistently remark that the quality of this material used in building human residences and other buildings was of superior quality than that used for the same purpose elsewhere in India. A few illustrative examples are supplied below.

James Anderson of Hermiston ${ }^{11}$ comments in the article on chūnnam by James Anderson of Madras (1799, p. 7):

No cement for building hath as yet been discovered in Europe that can be compared with the fine Chunam of India for closeness, toughness, durability, and beauty. It sets as quickly as stucco, and at the same time acquires a hardness greatly superior to our best lime mortar, and is alike proper for works underwater, as for those that are exposed to the air; so that it

\footnotetext{
${ }^{10}$ Massey \& Company Limited and Crompton Engineering Company were two engineering production and marketing firms in Madras, their Head Offices located in London. Both Massey \& Company and Crompton Engineering Company survived because of works contracted to them by the railway and public works departments of the Government in Madras.

${ }^{11}$ A clarification of James Anderson (J. A.) as 'J. A. of Hermiston' (Edinburgh, also referred as 'James Anderson, LL.D.') and James Anderson (J. A.) of Madras is necessary. J. A. of Madras, a medical doctor, served with the Madras Medical Corps. J. A. of Madras is referred as 'James Anderson, M. D.' Both J. A.-s were born in Hermiston: J. A. of Hermiston in 1739, J. A. of Madras in 1738. They were close friends (some suggest 'cousins') and intellectuals. Curiously, both died in 1809, one in Hermiston and the other in Madras. A life-size marble statue of J. A. of Madras exists in St. George's Cathedral, Cathedral Road, Chennai (Raman 2011, 2014).
}

supersedes the use alike of gypsum and of puzzuolana, or terras.

Reverend James Cordiner, a teacher at the Male Military Orphan Asylum in Madras ${ }^{12}$ between June 1798 and April 1799, and later Chaplain at the Government House, Colombo (Sri Lanka), while returning to Britain in 1802 from Colombo via Madras, comments appreciatively on the quality of chûnnam used in the then newly constructed Banqueting Hall ${ }^{13}$ and a few other new buildings in Madras. He also clarifies that the sparkling chûnnam was made by mixing lime and unrefined sugar — the jaggery $^{14}$ - in particular proportions, so that the chûnnamfinished walls were beautiful, enduring, and sparkled like marble.

Walter Hamilton in his travelogue - the Geographical, Statistical, and Historical Description of Hindostan, and the Adjacent Countries (1820, p. 193) —-says:

Chunam, or lime, occurs in extensive quantities among the boundary hills, and accessible during the rains, from whence it is transported by the inland navigation to the most distant parts of Bengal; but it is greatly inferior to the beautiful shell-chunam of Madras. A commerce in chunam, wax, ivory, and other

\footnotetext{
${ }^{12}$ The Male Military Orphan Asylum was established in Madras in 1789 to support the orphaned boys of Eurasian (Anglo-Indian) descent and provide some basic life skills to them (Penny 1904). This asylum trained them in various capabilities such as printing and minding military horses. Rev. Andrew Bell was the first Superintendent of this Asylum located in Egmore-Chintadaripet area of Madras city from 1789 to 1796. Bell pioneered in the monitorial method of teaching, which came to be known later as the 'Madras System of Education'. After Bell's return to Britain in 1796, this system of teaching and empowering was adopted in various schools in Britain. The Madras College (St. Andrews, Scotland) was established by Andrew Bell himself in St. Andrews, Scotland, implementing the Madras System of Education in 1833. The Madras College is operational today.

${ }^{13}$ The Banqueting Hall is a spacious building, presently known as the Rajaji Hall. This was built during the Governorship of Edward Clive (son of Robert Clive), by the well-known astronomer-engineer of Madras John Goldingham (Raman 2012) in honour of the victory of the British over Tipu in Mysore, between 1800-1802.

${ }^{14} \mathrm{Jaggery}$ is the unbleached, raw sugar from sugarcane juice (Saccharum officinarum, Poaceae). Jaggery is also made from Asian Palmyra (Borassus flabellifer, Arecaceae) by extracting and boiling the sap that oozes from the cut end of either the shoot bud or the inflorescence. It is the most abundantly available sugar source widely used by the less well-off rural people of India (Playne et al., 1914-1915).
} 
articles, is carried on with the Cosseahs ${ }^{15}$ and other mountaineers on the eastern frontiers of Bengal.

The Universal Technological Dictionary (Crabb 1833, Appendix, p. 8) indicates: 'Madras chunam, made from calcined shells, is the best.' Maria Callcott, a popular British writer and traveller of the 19th century and one who lived in Madras and Bombay in 1809-1811, describes in her book the Essays towards the History of Painting (1836, p. 220):

Panænus ${ }^{16}$ (the brother of Phidias) used a plaster or stucco in the Temple of Minerva at Elis, Southern Greece, mixed with milk. This should be something like the beautiful marblelike stucco or chunam-work of India, I once saw a floor laid at Madras, among the materials of which were jaggree (jaggery) or coarse sugar, water and milk.

Because of its quality and shine, the Madras chûnnam was preferentially chosen for use in several buildings in Singapore in the mid-19th century. The Government House and St. Andrew's Cathedral are two classic examples. To carry out this task, convicts deported from Madras, who were familiar with the technology, were used as labour (Tan 2016) (Figure 2).

\subsection{The Madras terrace roofs, unique construction using chûnnam}

Madras chûnnam was used both for fixing bricks and plastering wall exteriors. A popular component of human residences from the early decades of the 18th-century Madras was the 'Madras terrace roof' (MTR). Before the popularity of MTR in the 18th century, houses of middle- and low-income earners were essentially thatch roofed, using interwoven sun-dried plant materials (e.g., grasses and palm foliage) laid tightly on bamboo frames. MTRs were constructed using baked, red bricks $(15 \times 5 \times 1.2 \mathrm{~cm}$, achi-k-kal, arai-k-kal [Tamizh]) plastered with lime mortar, placed diagonally over $30-45 \mathrm{~cm}$ apart-wooden rafters. Wooden rafters held the baked, slender, red half-bricks

\footnotetext{
${ }^{15}$ Cosseahs - people belonging to the Khasi Hills of the Shillong Plateau, Meghalaya (Nongsiej 2002).

${ }^{16}$ Panænus: a painter in ancient Greece (c. 500 BCE) (Leake 1821).
}

(arai-k-kal) plastered along their left-right and frontback faces (Figure 3). If considered necessary, the MTRs were supported by wooden pillars (Punmia et al. 2005, Joseph 2018).

Frederick Hemingway (Collector and Magistrate of Trichnopoly [Tiruchirapalli]), comments on the houses in the district Tiruchirapalli in the first decade of the 20th century (1907, p. 81):

The houses of the poor are thatched. Persons of even moderate wealth build themselves terraced or tiled houses. Terraced houses are rare in Namakkal and Udaiyarpalaiyam taluks, where tiles are generally used. Terraced houses, in many other districts, are usually owned only by the wealthy. Two-storied houses are perhaps more common in this than in most other districts. Thatch is made of plaited cocoanut leaves covered with straw of various kinds. Occasionally a loft or mud terrace called kurangumacchu (a kind of mezzanine) is built beneath the roof. Houses are generally oblong in shape.

\subsection{How Madras chûnnam was made}

The limestone for making chûnnam was extracted from (1) inland quarries and (2) beached seashells. The latter was deemed of superior quality.

Pebbles or gravel stones were first pounded with handheld cylindrical wooden pounders $(1-1.5 \mathrm{~m}$ long, $5 \mathrm{~cm}$ thick) shod with iron crowns (ûlakkai, Tamizh) to separate the aluminous clay from them, followed by sorting into 'white' or 'dull-white' or 'brown' quality. The limestone from inland quarries was burnt by laying alternate layers of rock and charcoal in the ratio of 2:1 charcoal: limestone $\mathrm{CCaCO}_{3}$ (solid) + heat $\rightarrow \mathrm{CaO}$ (solid) $\left.+\mathrm{CO}_{2}\right]$. The burnt limestone was slacked by heaping them as mounds and adding water [CaO (solid) $+\mathrm{H}_{2} \mathrm{O}$ $\rightarrow \mathrm{Ca}(\mathrm{OH})_{2}$ (solid)]. As soon as the heat generated, the heaped material was thoroughly whisked and blended until it reduced to a dry powder $\left[\mathrm{Ca}(\mathrm{OH})_{2}\right.$ (solid) $+\mathrm{CO}_{2} \rightarrow$ $\mathrm{CaCO}_{3}$ (solid, powder lime) $+\mathrm{H}_{2} \mathrm{O}$ ] (Smith 1837).

The powder lime was used by the builders. Seashell chûnnam was produced nearly in the same manner, except that it was cleaned in a dry state by manually winnowing it against the wind. The burning process differed slightly. Charcoal was mixed with the shells and burnt 


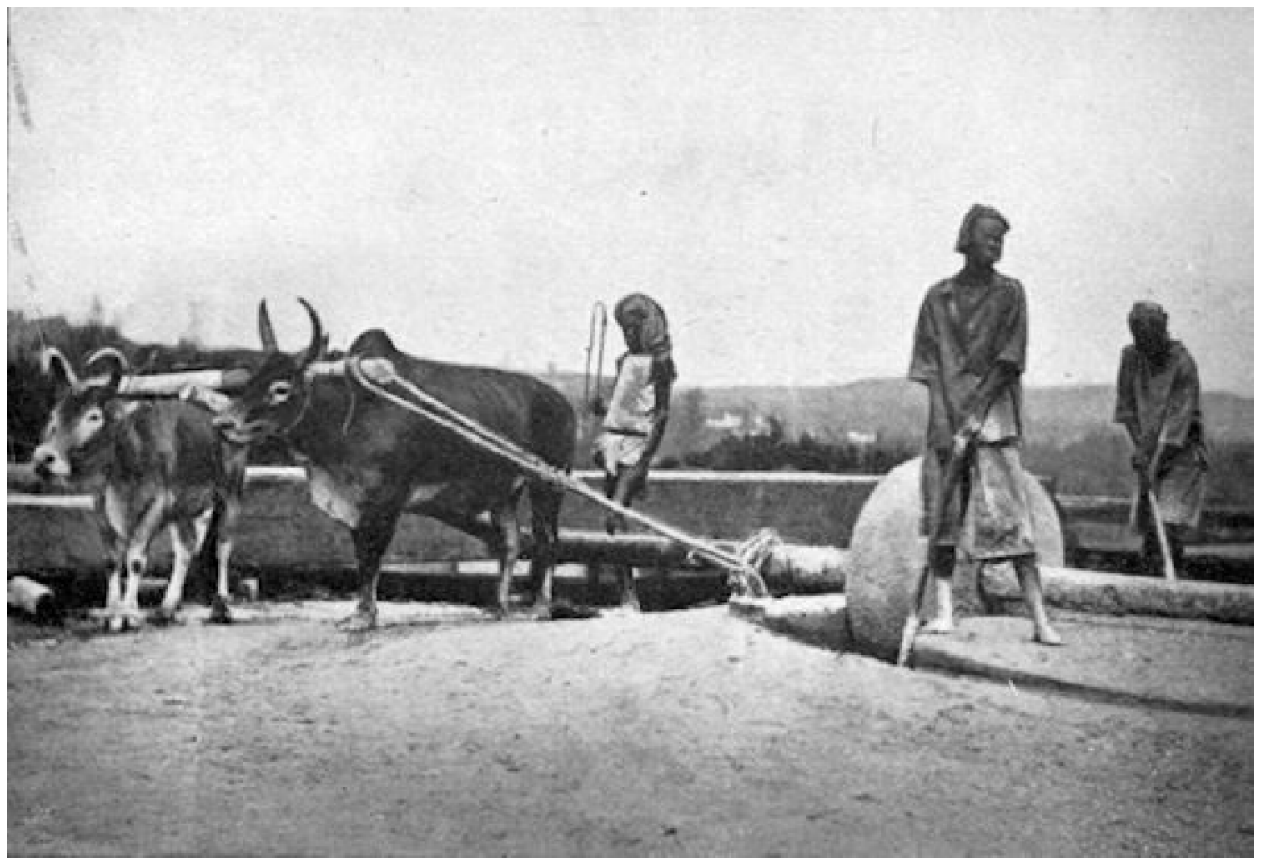

Figure 2 Mortar mill used while building the Government House, Singapore. (Source: McNair and Bayliss, 1899).

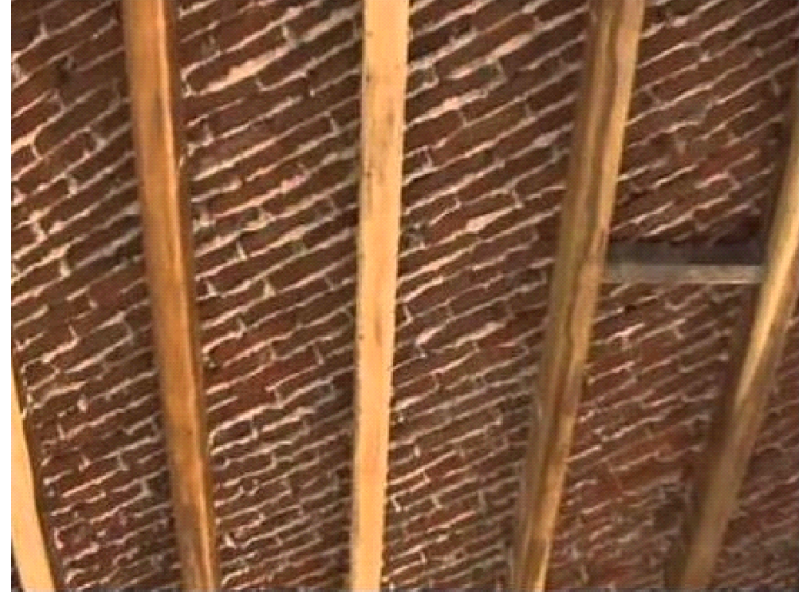

Figure 3 Inside view of Madras-terrace roof. (Source: https://www.pinterest.com.au/pin/ 36697306-9635001123).

in large open kilns with grated bottoms and longitudinal flues. These kilns communicated to the exterior usually with four, occasionally more, lateral windows to extract the finished product (Rāz 1834).

Thinly diluted chûnnam was used for whitewashing interiors of a house, which, rendered the washed walls marble-like, usually after three coats (Smith 1837). The lime extracted from well-washed seashells were calcined in designated kilns (ülai - National Centre for Safety of Heritage Structures [NCSHS] c/o- Indian Institute of Technology, Madras) ${ }^{17}$ during which the artisans took care to see that the brilliance of the lime remained unblemished. They made the plaster by mixing the burnt lime and river sand in the ratio of 1:1.5. They preferred river sand, because of its whiteness. The sand from other sources - they considered — would ruin brilliance. When white sand was not procurable, they ground locally available crystalline soil and pebbles (Benza 1837, Malcolmson 1838) into a fine powder and used.

Grinding was done in a large stone bowl (mortar) intended for this purpose. The ingredients were dumped into the bowl and as the grinding by a massive stone pestle went on, pulled either by humans or by using animal (usually, bulls) power, periodical moistening was done. However, moistening was scrupulous, since excess water damaged the preferred constitution of the ground paste. When the stone bowls and pestles were inaccessible, humans hand pounded the material using the ûlakkai. The ground plaster was scooped from the stone bowl and heaped as cones, which was a clever way of stor-

\footnotetext{
${ }^{17} \mathrm{http}$ ///www. ncshs.org/events/workshop/lectures/2. Lime Burning in India.pdf, accessed 19 August 2019.
} 
ing the freshly ground plaster, because that method of storage retained moisture in the stored mortar at the desired level for relatively long periods (Mehta and Barker 1994). Whenever the mortar had to be stored for longer than usual periods, a pit was dug at the apex of the conical stockpile, through which measured quantities of water were periodically added. That water, percolating through the stockpile, retained moisture (Holman 1840).

The main deity (mûlavar) of Ananta-śayana Mahā Viśnu in Sri Ranganātha temple, Srirangam, near Tiruchirapalli, is not made of granite as in temples dedicated to Mahādéva (Śiva) in southern India, but of stucco - a unique combination of chûnnam and baked bricks, plastered with a specially prepared balm (tailam) consisting of musk, camphor, honey, jaggery, and sandal. ${ }^{18}$ The chûnnam, intended for delicate ornate work, particularly in the vimānā-s and gôpurā-s (towers) in southern-Indian Hindu temples (Figures 4, 5) was hand ground, in small quantities, on a stone metate. ${ }^{19}$ The 3-storey tower in Figure 5 bears beautiful çunnāmpu sculptures (suthai-ççirpangal, Tamizh). This practice of incorporating stucco figures extended further with time across to other parts of southern India. For example, the prākērāa (cloister) in Virupākșa Kṣetra (Pampā Kșetra) in Hampi (Vijayanagara Empire, 13th-15th centuries) is ornate with several elegant stucco figures (Balasundaram 1948, Singh et al. 2018).

Jaggery was one key ingredient in preparing the chûnnam, especially that was used in plastering. Jaggery, because of its high-sugar content, was intentionally used to achieve intimate fusion of the coarse particles of lime (Rāz 1834).

\section{Engineer John Thomas Smith and the Lime Mortar of Madras}

John Smith (1805-1882), chief engineer with the Madras Engineers Corps (MEC), is immortalized in Madras for designing and building the Grecian-Doric column lighthouse in 1838-1839 (Raman 2016). Smith explored the

\footnotetext{
${ }^{18}$ UNESCO, n.d., https://whc.unesco.org/en/tentativelists/5894/, accessed 3 September 2019.

${ }^{19}$ Read as either 'metãtee or metãté (Spanish). A rectangular, granite block usually with a flat top. On the flat top, a heavy, hand-held granite mano (= a kind of rolling pin) is rolled repeatedly in a forwardbackward motion grinding the material.
}

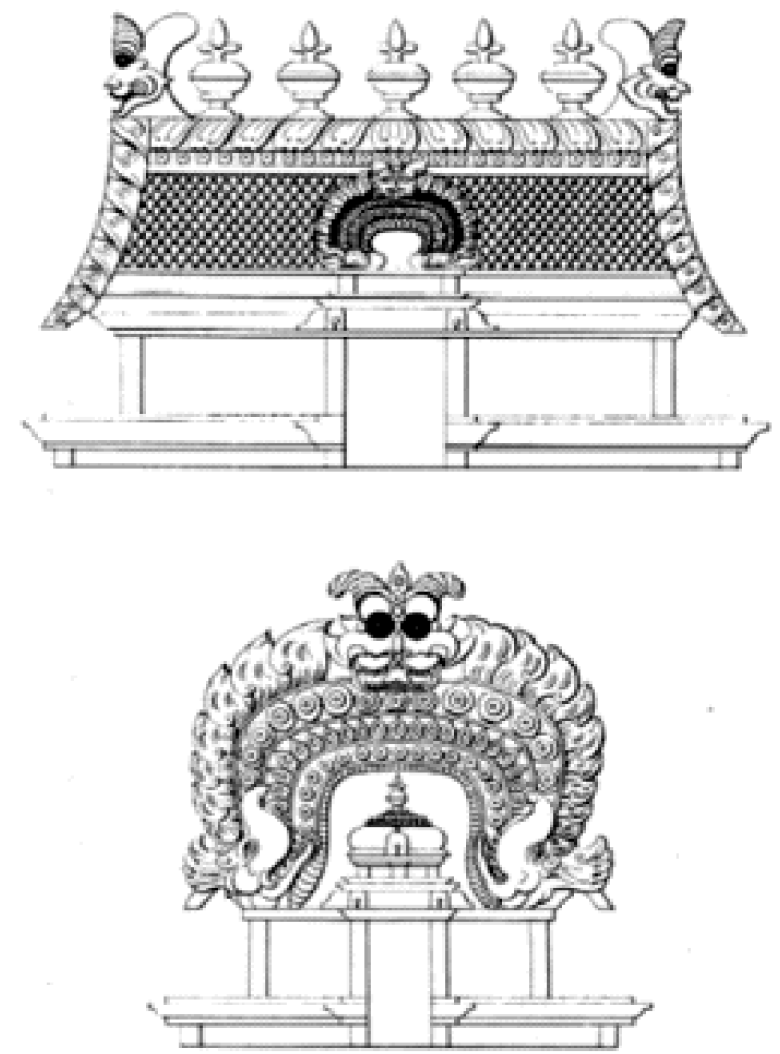

Figure 4 Ornate chûnnam work on the śikhara of the vimāna of a temple in the Madras presidency (Source: Rāz 1834, plate xxvi. Lithograph by William Day and Louis Haghe, London. Artist not identified).

science of limes and lime mortar used as building material. Many of the classy engineering papers and reports submitted to the government at Fort St. George (Madras) by MEC staff were published in the Reports, Correspondence and Original Papers on Various Professional Subjects Connected with the Duties of the Corps of Engineers Madras Presidency, edited and published by him from 1839. These papers enlighten us on some of the remarkable science that flourished in Madras. An incredible input Smith made to materials science is the translation of Louis-Joseph Vicat's ${ }^{20}$ Résumé des Connaissances Posi-

\footnotetext{
${ }^{20}$ Louis-Joseph Vicat (1786-1861) an engineer in Paris published extensively on the suitability of various limestones for the production of lime. He found that a mortar with hydraulic properties should include lime and either silica or alumina. He invented the method of testing the hydraulic properties of mortar, using the Vicat needle, which measured the setting time of mortars, used even today.
} 


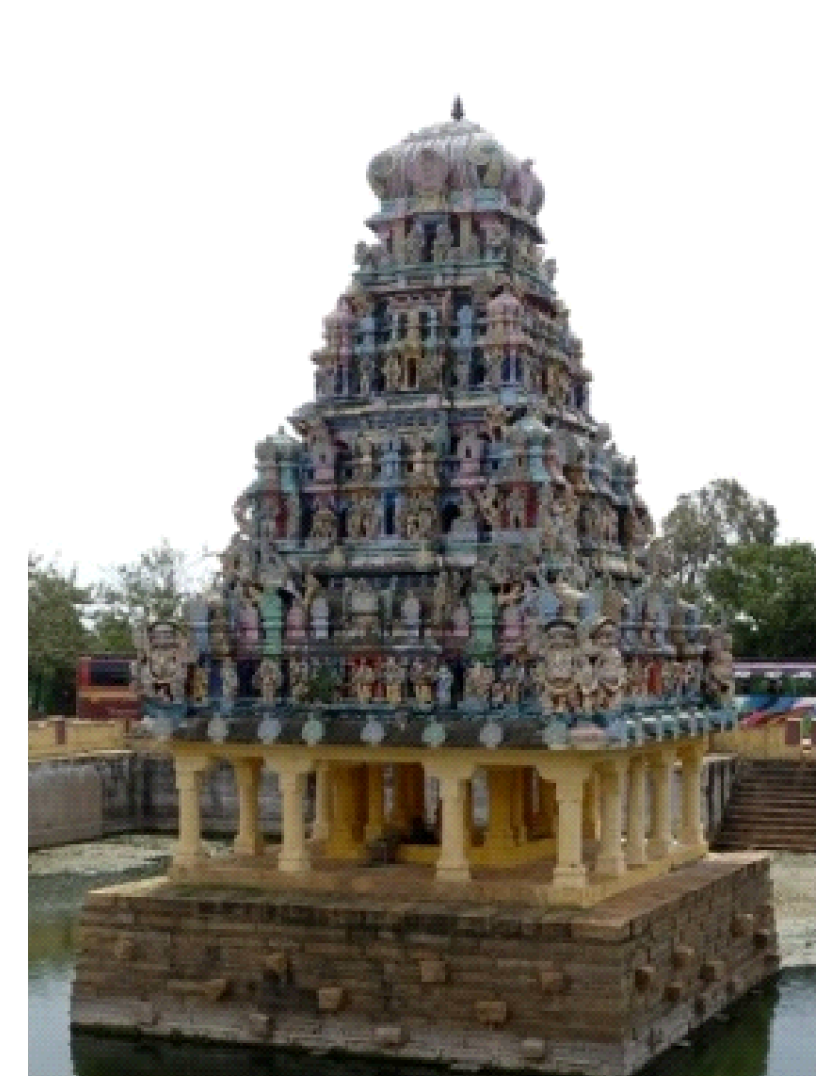

Figure 5 Neerãzhi mandapam (the hall in the middle of the temple tank) adjacent to the Chithira Sabai of Tiru-k-kutralanāthar temple management, Courtallam $\left(8^{\circ} 56^{\prime} \mathrm{N}, 77^{\circ} 16^{\prime} \mathrm{E}\right)$. (Photo: A. Raman, July 2018.). Estimated construction was either during the Vijayanagara Empire (14th17th centuries) or during the reign of the Madurai Nayak-s (16th-17th centuries). Recently it was colour-washed because of a festive event in Tiru-k-kutralanāthar temple.

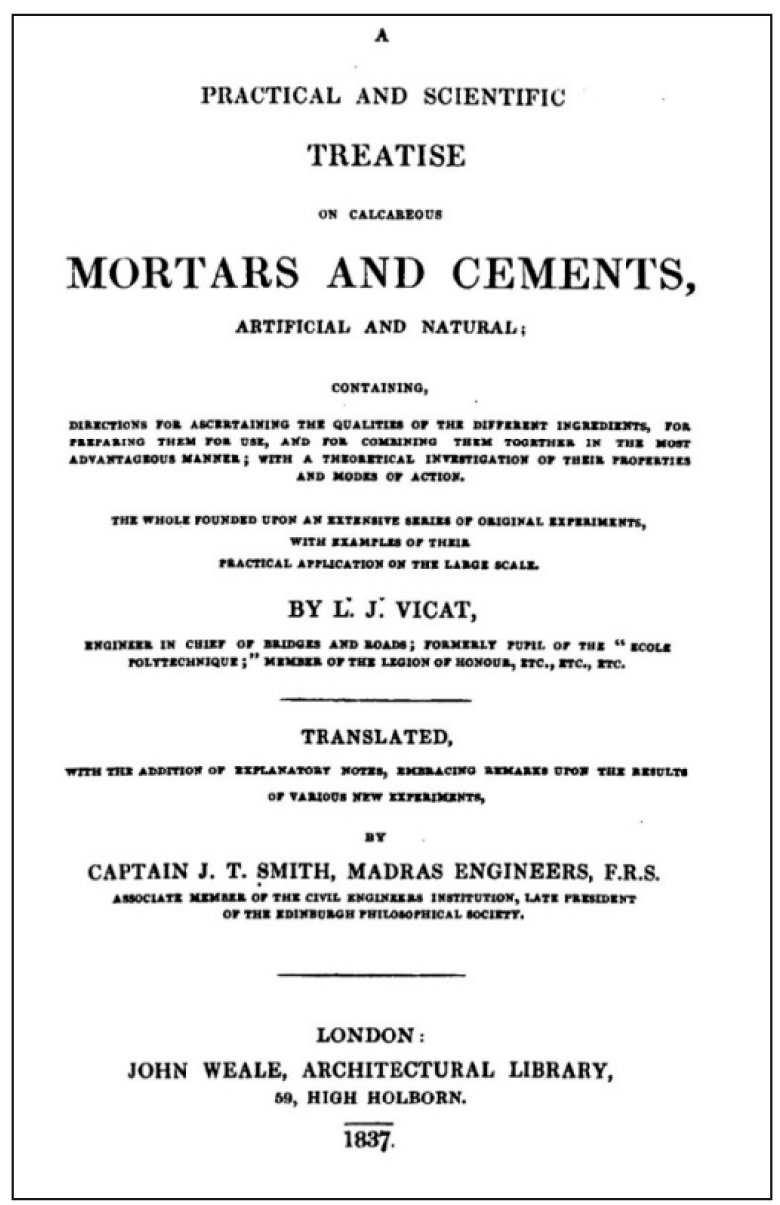

Figure 6 Cover page of the translated edition of Louis Joseph Vicat's book by J. T. Smith (1837).

tives Actuelles sur les Qualités, le Choix et la Convenance Réciproque des Matériaux Propres à la Fabrication des Mortiers et Ciments Calcaires suivi de Notes et Tableaux d'Expériences Justificatives (1828, l'Imprimérie de Firmin Didot, Paris, p. 149) into English (Smith 1837, Figure 6). The translation includes notes and comments on Madras chūnnam, based on experiments he made while stationed in Madras.

During Smith's time in Madras, extensive stretches of magnesite (source of $\mathrm{MgCO}_{3}$ ) were discovered in the Chalk Hills, Salem $\left(11^{\circ} 43^{\prime} \mathrm{N}, 78^{\circ} 7^{\prime} \mathrm{E}\right)$ and Tiruchirapalli $\left(10^{\circ} 48^{\prime} \mathrm{N}, 78^{\circ} 41^{\prime} \mathrm{E}\right)$. The estimates were that magnesite was available plentifully. Measures were already in place to explore these landscapes for use as a 'cement' source. Benjamin Heyne (1770-1819), a medical doctor and a 
noted botanist of India ${ }^{21}$, first discovered the availability of magnesite in the Chalk Hills in the early decades of the 19th century (Blanford 1865). In 1825, Alexander Macleod of the Madras Army established the hydraulic properties of magnesian limestone found in Salem region and brought that finding to Madras government's attention. The magnesia cement (Sorel Cement) of Salem magnesite was considered of superior quality (Cotton 1839). This material came into extensive use in India after John Smith experimentally verified its efficiency in construction work (Smith 1837).

Smith (1837) provides extensive scientific remarks on the physical, chemical, and engineering aspects of chûnnam used in Madras. The following paragraph refers to some of his key remarks.

Three coats were usually applied. The first coat of 1-1.5 cm thickness, intended as wall plaster, involved the application of a mixture of seashell lime and sand, tempered with jaggery solution. On drying, the second, prepared as a thinner solution was applied with the mixture of well-sieved, powdered seashell lime and finewhite sand. The second and the third coats of chûnnam usually did not include the addition of jaggery solution, because its dull-brownness was considered to tarnish the whiteness of the applied chûnnam-wash. The third, usually the last, coat was polished. The third coat chûnnam was prepared with extreme care. Only the whitest seashells with a small proportion of white sand were used. The components intended for the third coat were ground in a circular, granite-base channel in which a massive stone roller rolled grinding the chûnnam ingredients to a uniformly smooth, creamy paste. In a bushel (c. $27 \mathrm{~kg}$ ) of this paste, a dozen eggs, half a pound $(0.227 \mathrm{~kg})$ of ghee (clarified butter), and some freshly curdled yoghurt (quantity not specified) were added. To this composite, some of the master masons (maistry) added 110-225 g of balapong (soap-stone, steatite, metamorphic talc-schist), which ensured brilliance of the final coat. However every master

\footnotetext{
${ }^{21}$ https://plants.jstor.org/stable/10.5555/al .ap. person. bm000336083, accessed on 1 September 2019
}

mason had a recipe of his own. The essential ingredients, in addition to the lime and sand, were the albumen of eggs and the ghee. Sometimes an oil (not identified) was used instead of ghee. The final coat was always thin, and was applied usually before the second was fully dry. Because of the dilution and thinness, the third coat dried quickly. The washed walls were then scrubbed using the smooth surface of a handheld block of either balapong or agate. This procedure was done for several hours followed by wiping with a soft cotton fabric.

In the 'Memorandum of experiments upon the influence of jaghery in chunam' published (1839), Smith describes his experiments to establish the validity of using jaggery solution as a tempering agent while making the Madras chūnnam. He made six trials of mixing the mortar with (i) plain water, (ii) fresh-lime solution, (iii) $1 / 4 \mathrm{lb}(113 \mathrm{~g}$ ) of jaggery mixed in 1 gallon $(3.78 \mathrm{~L}$ ) of limewater, (iv) $1 / 2$ $\mathrm{lb}(227 \mathrm{~g})$ of jaggery mixed in 1 gallon $(3.78 \mathrm{~L})$ of limewater, (v) $1 \mathrm{lb}(453 \mathrm{~g})$ of jaggery mixed in 1 gallon $(3.78 \mathrm{~L})$ of limewater, and (vi) $2 \mathrm{lbs}$ (907 g) of jaggery mixed in 1 gallon $(3.78 \mathrm{~L})$ of limewater. He concludes that the use of jaggery as an additive to the chûnnam mortar is of special advantage, especially at the first hardening. He concludes that the jaggery is a highly useful material that acts as an efficient cohesive material in achieving a superior level of compaction of the chûnnam mortar, by enhancing the combining affinity of the lime. The proportion of jaggery used is indicated by Smith as follows (p. 129): 'no less than 10-20 lbs (4.53-9.07 kg) of jaggery per parrah ${ }^{22}$ (of chûnnam mortar) is necessary'. On the cohesive property of jaggery he says (p. 129):

The reason is, that the improvement made in the cohesion of the cement (mortar) depending only on the quantity of jaghery (jaggery) which remains within it after drying, must obviously be determined by the degree of saturation of the fluid of admixture, which regulates the quantity of the sugar which is left behind on desiccation.

\footnotetext{
${ }^{22}$ Parrah (read as 'parā') was a capacity measure widely used in South Malabar until recent times. One parā equalled approximately $40 \mathrm{lbs}$ of the measured item (Galletti et al., 1911, p. 42).
} 


\section{Discussion and Conclusion}

The remark that repeatedly occurs in the literature on Madras chûnnam is its marble-like finish. Almost every European, who had occasion to see and feel the chûnnam work in Madras consistently admired for its finished quality. Indeed, chûnnam was used in other parts of India for ages. However, the Madras chūnnam was considered marvellous. The Madras chûnnam was the material of choice in building works in Singapore of the Straits Settlements in the early- and mid-19th century.

Addition of various organic and inorganic materials to lime mortar was practiced elsewhere in the world from ancient times. For instance, in ancient China ground sticky rice $^{23}$ was added to lime mortar, which resulted in an organic-inorganic composite. The amylopectin of the sticky rice - the organic source (Yang et al. 2010) strengthened the mortar. Ancient Greeks supplemented lime mortar with straw and other fibrous materials. The straw as an additive enhanced plasticity and controlled setting rates; it enhanced strength and avoided cracks due to the shrinkage during setting (Moropoulou et al. 2005). Archaeological relics in the erstwhile Roman city of Sagalassos $\left(37^{\circ} 40^{\prime} \mathrm{N}, 30^{\circ} 31^{\prime} \mathrm{E}\right)$ reveal that the lime used was burnt from local Triassic limestones and prepared by dry slaking. The additives were crushed ceramics and volcanic ash (Degryse et al. 2002).

In Southern India in general, and in the Tamizh country in particular, several other biological materials were added to lime mortar to achieve quicker and better carbonation (hardening process). Carbonation renders the lime mortar durable. In the Madras presidency, builders and bricklayers added jaggery solution to limestone mortar. Egg albumin, clarified butter, and freshly curdled yoghurt, and talc schist (balapong) were the other additives, although the proportions of each item added varied with the understanding and experience of the maistry-in-charge of the building work (Smith 1837). Carbonation, a chemical process, depends on the atmospheric temperature, relative humidity, and the concentration of $\mathrm{CO}_{2}$ present. Carbonation results in the changed mass of the applied lime mortar by transforming the moist mortar into either dry

\footnotetext{
${ }^{23}$ Sticky rice, otherwise known as 'glutinous rice' (Oryza sativa var. glutinosa, Poaceae) has been in use in China for the last two millennia. This was also grown in many nations in South and South-eastern Asia. This rice includes little amylose and more amylopectins ( Li et al. 2017).
}

calcite or crystalline form of $\mathrm{CaCO}_{3}$ (argolite) with time. At the end, the applied mortar's mechanical strength enhances considerably and changes water-transport characteristics (Jayasingh and Selvaraj 2018).

Trials made with lime mortars (lime: sand-1:2) laid after 15 days of fermentation added with either extracts of or crushed plants (Cissus repens [Vitaceae], Cochlospermum religiosum [Bixaceae]), Persea macrantha [Lauraceae], Terminalia chebula [Combretaceae]) and jaggery made from either Borassus flabellifer [Arecaceae, the Asian Palmyra palm] or species of Saccharum [Poaceae, sugarcane]) to improve flexure, tension, and compressive strengths. The transverse strength of lime mortar supplemented with 5\% plant extracts was 1.6 times greater than the lime mortar supplemented with plain water. Additionally a 3-fold increase in tensile strength occurred because of the elastic nature of plant-material added lime mortar. The compressive strength enhanced up to 2.5 times on the addition of plant extracts (Thirumalini et al. 2011).

Jaggery was added during the preparation of lime mortar, which, as the sugar source $(65-80 \%)$ enhanced dissolution of lime in water. This was the reason why the maistry-s in the Tamizh country used jaggery solution during slaking process, which restrained the addition of water to lime directly, enabling the conversion of $\mathrm{CaO}$ into $\mathrm{Ca}(\mathrm{OH})_{2}$ :

$$
\begin{array}{r}
\mathrm{CaCO}_{3}+\text { heat } \rightarrow \mathrm{CaO}+\mathrm{CO}_{2} \\
\mathrm{CaO}+\mathrm{H}_{2} \mathrm{O} \rightarrow \mathrm{Ca}(\mathrm{OH})_{2}
\end{array}
$$

In the sesquicentennial restoration of the Church of Our Lady of Lourdes (St. Joseph's College precinct, Tiruchirapalli, consecrated in 1840) in the late 1990s, the restorers found that the earlier used plastering material included jaggery and Terminalia chebula ${ }^{24}$ (Combretaceae, myrobalan, kadukkāi-Tamizh) seed extracts, further to extracts of stems of Ipomoea staphylina (Convolvulaceae) (Natarajan et al. 2010). Why extracts of I. staphylina were

\footnotetext{
${ }^{24}$ Many authors incorrectly refer kadukkāi (Terminalia chebula) as 'gall nut(s)'. Gall nuts are dry, woody abnormal growths, referred as 'galls' induced on the leaves of species of Fagus (Fagaceae) by certain groups of insects (Cynipidea) and these are usually confined to cool regions of the world (e.g., Northern and Central Europe, Himalaya) They include abundant phenols as the seeds and fruits of kadukkāi do. Kadukkāi in popular English is myrobalan and not gall nuts. Images used by most of those authors erroneously indicate the insect-induced galls and not the fruits or seeds of kadukkāi.
} 
used is mysterious. Use of jaggery solution and extracts of T. chebula seeds is also known in the Charminar built by Mohammad Quli Qutb Shah in Hyderabad in 1591 (Singh 1993).

Jaggery and the crushed seeds of T. chebula were used as additives to achieve more rapid setting and better stabilization. These materials facilitated the initial consumption of lime altering the $\mathrm{pH}$ level, sufficiently high, rendering the available silica and aluminium soluble (James et al. 2018). As lime content increases above the initial consumption of lime, the residual Ca reacts with the soluble silica and aluminium triggering pozzolanic reactions. Such pozzolanic reactions will continue as long as the high-pH and residual Ca remain, leading to the formation of reaction products enhancing the setting and stabilization (Little 1995).

The above narrative brings to light some of the ignored, forgotten details of the plastering materials used in the 18th and 19th century Tamizh country, which impress as a giant leap in construction work, further to impressive sculpture work done using different rock materials. The Airawatéswara temple, $4 \mathrm{~km}$ south-west of Kumbhakonam, built by Raja Raja II (1146-1172 CE) of the later Çola dynasty will be one example. That apart, even for buildings human residences, that they made use of sophisticated technology in preparing appropriate paste of chūnnam and other materials in the most appropriate manner is indeed remarkable.

It does not surprise at all, therefore, why many of the contemporary construction engineers and architects are loudly talking on the validity and usefulness of using lime mortar, embellished with plant fibres and plant extracts, supplemented by traditional grinding done with bull-pulled stone grinders as referred at the start of this article.

\section{Acknolwedgements}

I am grateful to Thomas Lehmann (Sud-Asien Institut, University of Heidelberg, Heidelberg, Germany) and Venkat Prakash (Institut Français de Pondichéry, Pondichéry, India) for explanations to my inquiries on certain Tamizh-word etymologies and ancient Tamizh culture.

\section{Bibliography}

[1] Adams W. H. D. The Story of our Lighthouses and Lightships, Descriptive and Historical, Thomas Nelson \& Sons, London, 1891.

[2] Anderson of Madras J. An account of the mode of making the fine marble-like cement of India called chunam (with supplementary comments by James Anderson of Hermiston, the editor), Recreations in Agriculture, Natural-History, Arts \& Miscellaneous Literature, I (1799): 7-12.

[3] Atalkar P. S., Baraskar Y. B., Holey P., Deopujari J. Y., and Mandavgane S. A. Preparation and testing of herbal adamantine glue as described in Brhatsamhitā, Indian Journal of Traditional Knowledge, 5 (2006):259-262.

[4] Bagchi A. K. The Evolution of International Business, 1800-1945: Private Investment in India, 1900-1939, Taylor \& Francis, London, vol. 5, 1939.

[5] Balaji G. Discovering the sculptor of Mamallapuram, Journal of Indian History \& Culture, 23 (2017): 3440.

[6] Balasundaram A. K. Relics of the Vijayanagar Glory, Rayalaseema Krishnaraya Publishing Works, Anantapur, 1948, pp. $159+107$ 'pictures' in unnumbered pages.

[7] Benza P. M. Notes, chiefly geological, of a journey through the Northern Circars in the year 1835 , Madras Journal of Literature \& Science, VI (1837): 43-70.

[8] Blanford H. F. On the Cretaceous and other rocks of the South Arcot and Trichinopoly Districts, in: Oldham, T. (ed.), Memoirs of the Geological Survey of India, vol. 4, Government of India Press, Calcutta, 1865, pp. 1-221.

[9] Callcott M. Essays Towards the History of Painting. Edward Moxon, London, 1836.

[10] Cordiner J. A Voyage to India, Brown \& Co., Aberdeen; Longman, Hurst, Rees, Orme, \& Brown, London, 1820, p. 315. 
[11] Chakrabarti V. Indian Architectural Theory: Contemporary Uses of Vastu Vidya. Curzon, Surrey, 1998, pp. 212+xxii.

[12] Courland R. Concrete Planet: The Strange and Fascinating Story of the World's Most Common ManMade Material, Prometheus, Amherst, N.Y., 2011.

[13] Cotton A. T. Report upon the magnesia cement, Reports, Correspondence and Original Papers on Various Professional Subjects Connected with the Duties of the Corps of Engineers, Madras Presidency, 1 (1839): 28-31.

[14] Cotton A. T. Magnesia Cement, Papers on Subjects Connected with the Duties of Corps of Royal Engineers Contributed by the Officers of Royal Engineers, 1 (1845), 28-29.

[15] Crabb G. Universal Technological Dictionary (Familiar Explanations of the Terms Used in All Arts and Sciences), Baldwin \& Craddock, London, 1833, vol. I (no page numbers in the original, estimated number of pages: 760$)$.

[16] Crider A. F. Cement and Portland Cement Materials of Mississippi, Mississippi State Geological Survey: Bulletin, 1, 1907, 1-73.

[17] Davidovits J. La Nouvelle Histoire des Pyramides d'Egypte, Editions Jean-Cyrille Godefroy, Paris, 2006.

[18] Degryse P., Elsen J. and Waelkens M. Science of ancient mortars from Sagalassos (Turkey) in view of their Conservation. Cement and Concrete Research, 32 (2002): 1457-1463.

[19] Elliott H. M. (ed. by) Dowson J. The History of India as told by its Own Historians: The Mohammedan Period, Cambridge University Press, Cambridge, 1873 (reprint 2013).

[20] Galletti A., van den Burg A. J. and Groot P. The Dutch in Malabar being a Translation of Selections Nos. 1 and 2 with Introduction and Notes, Selections from the Records of the Madras Government, Dutch Records No. 13, Superintendent, Government Press, Madras, 1911.
[21] Hamilton W. Geographical, Statistical, and Historical Description of Hindostan, and the Adjacent Countries, John Murray, London, vol. I, 1820, pp. 766.

[22] Hemingway F. R. Trichinopoly, Madras District Gazetteers, Superintendent, Government Press, Madras, 1907, pp. 400.

[23] Holman J. Madras, Ceylon, Mauritius, Cormoro Islands, Zanzibar, Calcutta, \& Etc., \& Etc. George Routledge, London, vol. III, 1840, pp. 473.

[24] Indorf P. Interpreting the Hindu temple form: a model based on its conceptualization as a formal expression of measured movement, Artibus Asiae, 64 (2004): 177-211.

[25] James J., Karthickeyan S., Chidambaram S., Dayanandan B., and Karthick K. Effect of curing conditions and freeze-thaw cycles on the strength of an expansive soil stabilized with a combination of lime, jaggery, and gallnut powder, Advances in Civil Engineering, article ID 1813563, 2018, doi:https: //doi.org/10.1155/2018/1813563.

[26] Jana D. The Great Pyramid debate: Evidence from detailed petrographic examinations of casting stones from the Great Pyramid of Khufu, a natural limestone from Tura, and a man-made (geopolymeric) limestone. Proceedings of the 29th Conference on Cement Microscopy, edited and published by the International Cement Microscopy Association, Quebec City, 2007, pp. 207-265.

[27] Jayasingh S. and Selvaraj T. Study on carbonation initiated by organics in traditional lime mortar. In: Structural Analysis of Historical Constructions: An Interdisciplinary Approach, Aguilar, R., Torrealva, D., Moreira, S., Pando, M. A. and Ramos, L. F. (eds.), 18 (2018): 421-428.

[28] Joseph P. Native roofing systems of South India: Processes and Material Heritage, Sahapedia, https://www.sahapedia.org/nativeroofing-systems-of-south-indiaprocesses and-material-heritage, accessed on 29 July 2019. 
[29] Lal B. The Earliest Civilisation of South Asia: Rise, Maturity and Decline, Aryan Books International, Delhi, 1997, pp. 308.

[30] Lamprecht H.-O. Opus caementicium, in: Encyclopaedia of the Ancient World, Brill's New Pauly, Antiquity volumes (Prol-Sar), H. Cancik and H. Schneider (eds), translated by C. F. Salazar, Brill, Leiden, 12 (2008): 1-496.

[31] Leake W. M. The Topography of Athens with Some Remarks on its Antiquities, John Murray, London, 1821, pp. 435.

[32] Li H., Fitzgerald M. A., Prakash S., Nicholson T. M., and Gilbert R. G. The Molecular Structural Features controlling Stickiness in cooked rice, a major palatability determinant, Scientific Reports, 7 (2017), doi: $10.1038 /$ srep43713

[33] Little D. N. Handbook for Stabilization of Pavement Subgrades and Base Courses with Lime, Kendall Hunt Publishing Company, Austin, TX, USA, 1995, pp. 219.

[34] Malcolmson J. G. On the fossils of the eastern portion of the Great Basaltic District of India, The Athencum (1838): 18 (no volume number available).

[35] McNair J. F. A. and Bayliss W. D. Prisoners their Own Warders: a Record of the Convict Prison at Singapore in the Straits Settlements Established 1825, Discontinued 1873, Together with a Cursory History of the Convict Establishments at Bencoolen, Penang, and Malacca from the Year 1797, Constable \& Company, Westminster, 1899, pp. 191.

[36] Mehta A. and Barker G. C. The dynamics of sand, Reports in Progress of Physics, 57 (1994): 383-416.

[37] Moropoulou A, Bakolas A. and Anagnostopoulou S. Composite materials in ancient structures, Cement and Concrete Composites 27 (2005): 295-300.

[38] Natarajan C, Chen S-E, and Syed M. Rehabilitation and preservation of St. Lourdes Church, Tiruchirapalli, Journal of Performance of Constructed Facilities, 24 (2010): 281-288.
[39] Nongsiej T. Khasi Cultural Theology, Indian Society for Promoting Christian Knowledge, Delhi, 2002, pp. 84.

[40] Ofori G. Nature of the construction industry, its needs and its development: a review of four decades of research. Journal of Construction in Developing Countries, 20 (2015): 115-135.

[41] Penny F. The Church in Madras: Being the History of the Ecclesiastical and Missionary Action of the EastIndia Company in the Presidency of Madras, John Murray, London, 1904, pp. 702.

[42] Playne S., Bond J. W. and Wright A. Southern India: its History, People, Commerce, and Industrial Relations, The Foreign and Colonial Compiling and Publishing Company, London, 1914-1915, pp. 766.

[43] Punmia B. C., Jain A. K., and Jain A. K. Building Construction, Laxmi Publications, New Delhi, 2005, pp. 846.

[44] Raddock, E. Listen how the wise one begins construction of a house for Viṣnu: vijānatā yathārabhyam grhaṃ vaiṣnavam śṛnv evaṃ, Chapters 1-14 of the Hayaśīișa Pañçarãtra, Ph.D. dissertation, University of California, Berkeley, pp. 300, California Digital Library, 2011, https://escholarship. org/content/qt83r393vc/qt83r393vc.pdf, accessed on 25 August 2019.

[45] Raman A. Economic biology and James Anderson in eighteenth-century Coromandel, Current Science, 100 (2011): 1092-1096.

[46] Raman A. Looking back: Goldingham and the Madras Observatory, Madras Musings, XXII (2012): 5-6.

[47] Raman A. More about Dr James Anderson's Madras contributions: beyond botany to medicare, Madras Musings, XXIII (2014): 7.

[48] Raman A. The Grecian Doric column lighthouse of Madras (1840) and its builder John Thomas Smith, Madras Army Corps of Engineers. Current Science, 111 (2016): 1107-1111.

[49] Ramaswami N. S. Indian Monuments, Abhinav Publications, New Delhi, 1971, pp. 192. 
[50] Rāz R. Essay on the Architecture of the Hindús, Royal Asiatic Society of Great Britain and Ireland, London, 1834 , pp. $64+48$ plates.

[51] Rinde M. Hard-headed man. Distillations of the Chemical Heritage Foundation, 1 (2015): 36-37.

[52] Sastri V. S. and Bhat, M. R. Varaha Mihira's Brihatsamhita with an English Translation and Notes. V. B. Soobbiah \& Sons, Bangalore, 1946, p. 804+68+214.

[53] Singh M. Analysis and characterization of Charminar lime plaster, Current Science, 64 (1993): 760764.

[54] Singh M., Waghmare S., and Kumar S. V. Characterization of lime plasters used in the 16th century Mughal monument, Journal of Archaeological Science, 42 (2014): 430-434.

[55] Singh M., Jumar S. V., and Sabale P. D. Chemical and mineralogical investigations of lime plasters of medieval structures of Hampi, India, International Journal of Architectural Heritage, 2018, doi: 10.1080/15583058.2018.1469175.

[56] Smith J. T. (Translator and Editor), A Practical and Scientific Treatise on Calcareous Mortars and Cements, Artificial and Natural: Containing Directions for Ascertaining the Qualities of the Different Ingredients, for Preparing them for Use, and for combining them Together (Original in French by Louis Joseph Vicat) with the Addition of Explanatory Notes, John Weale, London, 1837, pp. 306.

[57] Smith J. T. Memorandum of experiments upon the influence of jaghery in chunam. Reports, Correspondence and Original Papers on Various Professional Subjects Connected with the Duties of the Corps of Engineers, Madras Presidency, 1 (1839): 119-130.

[58] Srinivasachari C. History of the City of Madras, Written for the Tercentenary Celebration Committee, P. Varadachary \& Co., Madras, 1939, pp. 363.

[59] Tan B. Convict labour in colonial Singapore, Biblioasia, 11 (2016): 37-41.

[60] Thirumalini P., Ravi R., Sekar S. K. and Nambirajan M. Study on the performance enhancement of lime mortar used in ancient temples and monuments in India, Indian Journal of Science \& Technology, 4 (2011): 1484-1487.

[61] Tuan A. Y. and Shang G. Q. Vibration control in a 101-storey building using a tuned mass damper, Journal of Applied Science and Engineering, 17 (2014): 141-156.

[62] Yang F. W., Zhang B. J., and Ma Q. L. Study of Sticky Rice-lime mortar technology for the restoration of historical masonry construction, Accounts of Chemical Research, 43 (2010): 936-944. 